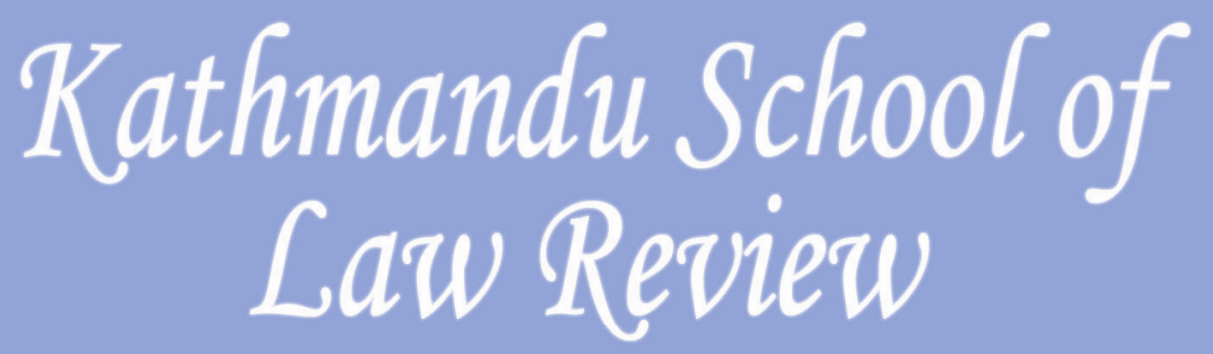

ISSN 2091-2110

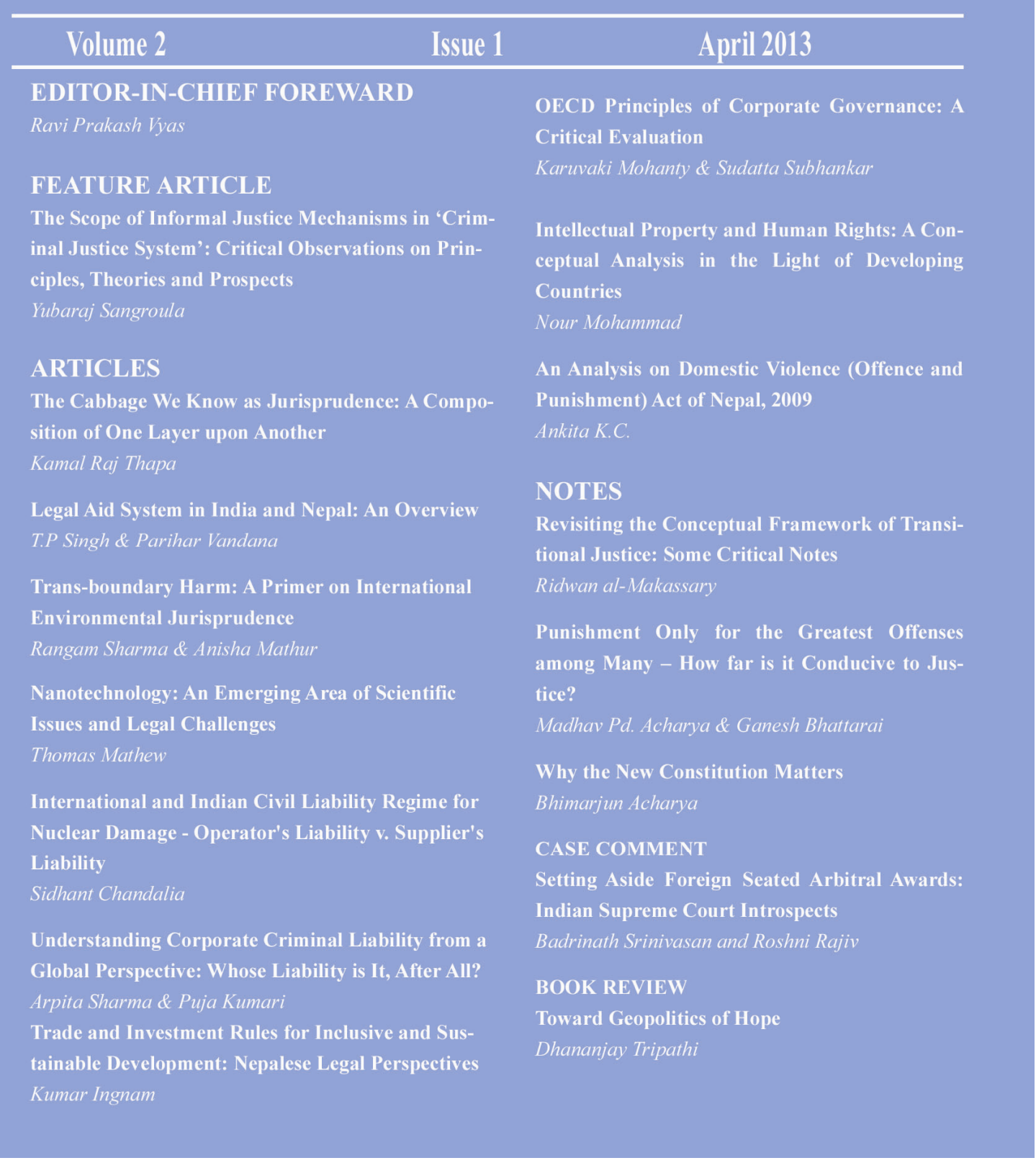




\title{
OECD Principles of Corporate Governance: A Critical Evaluation
}

\author{
Karuvaki Mohanty \& Sudatta Subhankar ${ }^{1}$
}

\begin{abstract}
The Organization for Economic Co-operation and Development (OECD) Principles of Corporate Governance comprises of certain elements of corporate governance significant for the purpose of managing a corporation. It ensures good corporate governance in the OECD as well as the non-OECD countries. It came into existence for the reconstruction of a devastated market system by application of US-financed Marshall Plan after World War II. The first set of OECD principles on good corporate governance were published in 1999 and revised in 2004. It includes the rights and treatment of shareholders, the role of stakeholders in corporate governance and their rights and responsibility of the board for disclosures and maintenance of transparency. These principles have been used extensively for framing a policy dialogue for the purpose of promoting regional corporate governance reforms and roundtables in nonOECD member countries as well. Since 1995, India has been associated with $O E C D$, as non-member economy. The corporate governance code of India has major provisions in compliance with the OECD principles. These principles can be criticized on the basis of certain issues such as its convergence towards the anglo-American way of corporate governance, the share-holder's primacy form of governance which negates the stakeholders' interest. But on the other hand, these principles alter the corporate governance systems of the countries to attract and suit foreign investors. Besides its adoption, proper implementation is essential, which includes having a proper corporate governance code, an audit committee, principle of accountability and director's responsibility of acting with due diligence and proper care.
\end{abstract}

\section{Introduction}

Corporate Governance is not only one of the key elements in improving economic efficiency of a company but also involves the management of a company and the relationship between its board, the shareholders and other stakeholders. ${ }^{2}$ Presence of a good

\footnotetext{
$1 \quad 4^{\text {th }}$ year BBA LLB(H) National Law University, Odisha

2 Thomas Clarke, International Corporate Governance a Comparative Approach (Routledge 2007).
} 
corporate governance system within a company and an economy provides a degree of confidence which is essential for the proper functioning of the company. ${ }^{3}$ The objective of incorporating these principles is to ensure increased transparency, integrity and rule of law in the management of a company. ${ }^{4}$ Effective corporate governance helps in building confidence in an economy for proper functioning of the market. ${ }^{5}$ The main aim of this project is to critically analyse the guidelines provided under the OECD principles in relations to the rights and treatment of the shareholders, stakeholders and to find out whether the elemental objective of having an effective and transparent regulatory mechanism is being achieved or not.

The basic element of corporate law is trust and principles of good corporate governance are essential for the smooth functioning of a corporation. The investors would invest in a company only if a company has a good corporate governance system and is able to gain the trust and confidence of the investors, the shareholders and the creditors. ${ }^{6}$ OECD Principles of Corporate Governance comprise of certain good elements of corporate governance which are significant for the purpose of managing a corporation. ${ }^{7}$ The OECD principles are a set of guidelines for ensuring good corporate governance in the OECD as well as the non-OECD countries.

\section{History and Development}

After the World War II, the economy of Europe was in a wreck and this gave rise to the Organisation for European Economic Cooperation (OEEC) for the reconstruction of a devastated market system by the application of US-financed Marshall Plan. The OECC members signed the OECD convention and then OECD was officially established in 1947. There are 34 member countries as of the date. ${ }^{8}$ The OECD aims at strengthening the economic systems of its member countries, improving efficiency, honing market systems, expanding free trade and contributing to development in developed as well as developing countries. ${ }^{9}$ The economy and national wealth of developed countries has reached great

Ibid.

Behdad Nowroozi, 'OECD Principles of Corporate Governance and International Financial Structure' (2002) <http://www.afdc.org.cn/upload/9/downloads/s1.3Behdad\%20Nowroozi.pdf>, accessed 4 August 2012

5 OECD, OECD Principles of Corporate Governance OECD Publications Service 2004).

$6 \quad$ Christine A. Mallin, Corporate Governance ( $3^{\text {rd }}$ edn, Oxford University Press 2010) 37.

7 Dr PT Giridharan, 'Principles of Corporate Governance: OECD Annotations to Indian Connotation' <http://www.icai.org/resource_file/8141Principles\%2520of\%2520Corporate\%2520Governance\% $2520 \%$ 2520OECD\%2520Annotations\%2520and\%2520Indian\%2520Connotations\%5B1\%5D.pdf>, accessed 4 August 2012.

8 <http://www.oecd.org/pages/0,3417,en_36734052_36761863_1_1_1_1_1,00.html>, accessed 29 March 2012 .

9 http://www.oecd.org/document/63/0,3746,en_2649_201185_1876671_1_1_1_1,00.html>, accessed 29 March 2012. 
heights with the establishment of OECD. The developing countries like India and Brazil are all not far behind and have emerged as huge economic giants in the recent times. ${ }^{10}$

Taking into account the need for a standard set of corporate governance principles in the developing economic system of today's world, the first set of OECD principles on good corporate governance were published in 1999. These principles are being widely followed and have proved to be a benchmark for corporate governance code in both OECD and NonOECD countries. The principles are designated one of the $12 \mathrm{key}$ standards for sound financial systems. ${ }^{11}$

The OECD Steering Group on Corporate Governance undertook the revision of the Principles under a mandate from OECD Ministers in 2002. This review was based on the practical experience of the member countries in dealing with the challenges faced by them in field of corporate governance. ${ }^{12}$ The revised principles were published in 2004. Certain issues that were addressed by the revised principles were:

Institutional investors: It propounded that the institutional investors should disclose corporate governance policies, disclose the method in which they decide on the use of their voting rights and how to manage conflict of interest. Another important point concerning restrictions on consultations between shareholders about their voting intentions should be eased to reduce the cost of informed ownerships was also mentioned in the revised principles.

Shareholder rights: This principle enables the shareholders to remove board members and participate effectively in the nomination and election processes, give their opinions about executive and board remuneration policy and have the power of approving in certain situations related to such policies.

Conflicts of interest and auditor responsibility: A new principle was introduced which requires rating agencies and analysts to avoid conflicts of interest which could compromise their advice. The auditors' duty has been strengthened and the auditors are required to be accountable to the shareholders and under an obligation to act under due diligence and take professional care while carrying out the audit activities. The necessity of wholly independent auditors was given in the revised principles.

Stakeholder rights and whistle-blower protection: The rights of the stakeholders were emphasized under this head and it was given that the whistle-blowers should be given protection. It propounded a mechanism through which their complaints can be taken care of and states that they can have a confidential communication with the board members.

\footnotetext{
$10 \quad$ OECD (n 5)

$11<$ http://www.oecd.org/document/22/0,3746,en_2649_37439_31558102_1_1_1_37439,00.html>, accessed 1 April 2012.

12 Clarke (n 2).
} 
Board responsibilities: Under this head, it is stated that the duties of the board members are fiduciary in nature. The board's independence was given emphasis and it was provided that there should be objectivity for the purpose of avoiding conflicts of interest. The board has responsibility of having an oversight of internal control systems and also the financial reporting. 13

\section{Brief Analysis of the OECD Principles of Corporate Governance}

Rights and treatment of the Shareholders: Great emphasis is laid on the rights of the shareholders and a detailed framework of rights has been provided under this head. This principle states that under a good corporate governance regime, it is very essential to protect the rights of the shareholders. The basic rights mentioned here are the right to transfer shares, the right to vote, the right to secure methods of ownership registration, the right to conduct annual general meetings and the right to elect and remove board members. It also entitles the shareholders to share profits of the corporation. The concept of proxies in situations when the shareholders are absent is also provided under this principle. After the revision in 2004, this principle also includes the rights and duties' of the institutional investors along with the rights of other shareholders. ${ }^{14}$

The rights given to the shareholders will ensure their active participation in the meetings and other activities of the corporation. This would facilitate better development of corporate market and would encourage foreign investors to invest in the company. On the other hand, such wide variety of rights given to the shareholders may also prove to be detrimental to the interest of the corporation. The interest of the company will be affected if the shareholders are not efficient enough to take important decisions regarding the election, removal of board members and other essential functions relating to the smooth functioning of the company.

Moreover, the inadequacy of information about the whereabouts of the company can also be attributed to the shareholders. In certain situations, the shareholders are not as well informed as the directors of the company and are inexperienced as regards to time management, education, experience and business judgment. The institutional investors are also not as well informed as the directors as regards to the company's affairs. ${ }^{15}$

Another opposition is that providing voting rights would allow shareholders to pursue their individual interests rather than the interests of the shareholders as a group. Moreover, there is a possibility of abuse of the power given to the shareholders. ${ }^{16}$ Therefore, it is very

$\operatorname{OECD}(\mathrm{n} 8)$.

OECD (n 9).

Julian Velasco, 'Taking Shareholder Rights Seriously'

<http://lawreview.law.ucdavis.edu/issues/41/2/articles/DavisVol41No2_Velasco.pdf> accessed 2 April 2012.

16 Louis Lowenstein, 'Pruning Deadwood in Hostile Takeovers: A Proposal for Legislation' 83 Columbia Law Review 249. 
essential to hold them accountable for their activities while taking important decisions on behalf of the corporation.

The OECD principles also lay down the principle of equitable treatment of all the shareholders including the minority shareholders and the foreign shareholders. This principle is beneficial for the minority shareholders and safeguards them against oppression.

\section{Stakeholders- Their Role in Corporate governance and Their Rights}

It can be argued that the current failures of corporate responsibility are not only failures of legal compliance, but also primarily failures to do what is ethical. ${ }^{17}$ In the recent times, corporate governance has laid great emphasis on public interest because of its apparent importance for the economic health of corporations and society in general. ${ }^{18}$ Therefore, it is essential to bring the rights of the stakeholders in the purview of corporate governance to maintain corporate social responsibility. The role of stakeholders' was first introduced under the OECD principles of corporate governance. Stakeholders play a very important role in the development of a corporation and therefore it is very essential to provide them with a certain set of rights. Protecting the interest of the various stakeholders which is a very essential part of corporate governance system, the OECD principles have also provided certain rights to the stakeholders. The stakeholders' rights are to be respected and they should be provided with an opportunity for an effective redress in situations of violation of their rights. The employees should be encouraged to participate in various activities of the corporation. They should be allowed to have access to adequate information so that they can contribute in the process of corporate governance. ${ }^{19}$ There should be a proper insolvency framework and importance should be attached to the protection of rights of the creditors. ${ }^{20}$

Stakeholder theory develops from the principle of corporate social responsibility which attaches importance to values and responsibilities towards the stakeholders of a corporation. But the basic problem in the OECD principles of corporate governance is that the principle as regards rights of the stakeholders does not provide an elaborate detail of the rights. The rights are very limited as compared to the wide range of rights provided to the shareholders.

\section{Responsibility of the Board: Disclosures and Maintenance of Transparency}

Corporate governance is an important condition to have an ethically based direction and management and fulfils the need for a corporation to be accountable. ${ }^{21}$ Corporate

Surendra Arjoon, 'Corporate Governance: An Ethical Perspective' ( 2005) 61 Jnl of Business Ethics 343. Ibid.

David Paas, 'Stakeholders and Participation in Corporate Governance: A Critique of Some of the Arguments Author' (1996) 15 Jnl of Business \& Professional Ethics 4.

$20 \quad$ OECD (n 11).

21 Herman Siebens, 'Concepts and Working Instruments for Corporate Governance' (2002) 39 Journal of Business Ethics 109. 
governance and ethics are connected, which includes board's juridical responsibilities: statutory responsibilities, controlling responsibilities, financial responsibilities, social obligations, fiscal and social-fiscal obligations, environmental responsibilities etc. ${ }^{22}$ These responsibilities of the board are extensively provided in the OECD principles of corporate governance.

The factor determining the success of a corporate governance structure is the extent to which it is transparent to market forces. ${ }^{23}$ To achieve this objective, it is very essential to have a strong disclosure regime as this would promote transparency and work as an effective monitoring system for a market based economy. The OECD principles include disclosure requirement such as disclosures related to financial status of the corporation, related party transactions, share ownership etc. The board has responsibility to act with due care and diligence and look into the interest of the stakeholders while discharging its duties. The key functions of the board would include reviewing and guiding corporate strategy, major plans of action, risk policy, annual budgets and overseeing major capital expenditures and acquisitions. The board has responsibility to monitor the effectiveness of corporate governance practice and other fiduciary responsibilities towards the corporation.

The board of directors of a corporation possess the responsibility to oversee all the activities of the corporation. They make overall policy decisions on behalf of the shareholders and monitor the working of the corporation. The basic duties of the board are fiduciary responsibility such as reviewing the functioning of a corporation and conducting annual meetings. ${ }^{24}$ The OECD principles of corporate governance provides for great responsibilities of the board members as to disclosures and maintaining transparency which is very essential for the smooth functioning of a corporation.

\section{OECD Principles in Relation to Non-OECD Countries}

The principles of OECD are also adopted by Non-OECD countries. During the formulation of the revised Principles of 2004, recent lessons and conclusions from non-OECD countries were also taken into account. This was to continue to maintain their global relevance in the corporate market. $^{25}$ These principles can act as a blueprint for the establishment of a modern, outward-looking confident economy in developing countries or the Non- OECD countries. $^{26}$

\footnotetext{
$22 \quad$ Ibid

23 C. J Carla and others, 'Corporate Governance and Institutional Transparency in Emerging Markets' (2005) $59 \mathrm{Jnl}$ of Business Ethics 163.

24 Jean Murray, 'Duties of a Corporate Board of Directors', <http://biztaxlaw.about.com/od/startingacorporation/a/boardduties.htm> accessed 1 April 2012

25 Fianna Jesover \& Grant Kirkpatrick, 'The Revised OECD Principles Of Corporate Governance And Their Relevance To Non-Oecd Countries'<http://www.oecd.org/dataoecd/41/38/33977036.pdf> 2 April 2012

26 A.S. Reid, 'The Internationalization of Corporate Governance Codes of Conduct' (2004) 24 Bus. Law Rev. 223, 238
} 
These principles have been used extensively used for framing a policy dialogue for the purpose of promoting regional corporate governance reforms and roundtables in nonOECD member countries. The Asian Corporate Governance Roundtable is being held since 1999. Most of the Asian countries that participate in this roundtable confirm the adaptability of the OECD principles by various countries with different legal, economic and cultural scenario. ${ }^{27}$

These roundtables have come up with certain suggestions for improving the corporate governance regime in the developing countries like strengthening effective legal enforcement, strengthening and protecting shareholders, particularly minority owners, dealing with conflict of interest and strengthening company oversight by boards. ${ }^{28}$

The participation of non-OECD countries in these roundtables makes it very clear that these countries are interested in application of OECD principles in their respective corporate law regimes. OECD's Centre for Co-operation with non-members develops and oversees the strategic orientation of the relationship of OECD and the non-OECD economies. The basic aim is to ensure that the dialogue between the country and OECD is based on development and results in mutually benefits. ${ }^{29}$

The Global Relations of the Organisation is handled by the Global Relations Secretariat. The OECD senior management is also assisted by the GRS in the strategic planning and prioritisation of its work with non-Members and with other international organisations for ensuring that the work programme is coherent and is implemented in accordance with the Secretary-General's strategic objectives. ${ }^{30}$ GRS also promotes the participation of the nonmembers in OECD Committees and their adherence to OECD standards and instruments. ${ }^{31}$

\section{Relevance of OECD Principles in India}

OECD has working relations with many non-member countries. India is one of the many non-member economies. Since 1995, India has been associated with OECD. ${ }^{32}$ A resolution was adopted on 16 May 2007 by the OECD Council at Ministerial level to strengthen the co-operation with India through a programme of enhanced engagement. ${ }^{33}$ Other countries which are parties to this resolution are Brazil, China, Indonesia and South Africa. ${ }^{34}$ This

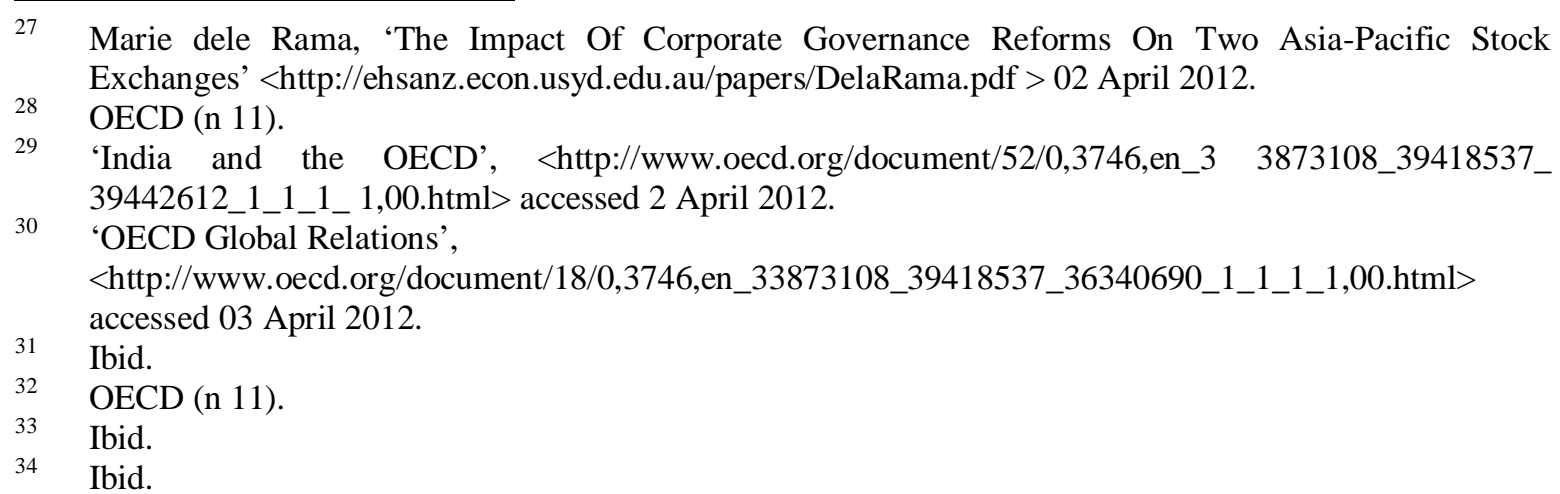


development further increases the possibilities of India being a member of OECD in near future. There are several opportunities to discuss major policy issues and face challenges and also to learn from the experiences of OECD countries facing similar challenges. The OECD countries and non-OECD economies, who are increasingly engaged with India through trade and investment also benefit from the relationship of India and OECD as India has now become a successful player in the global market. ${ }^{35}$ India participates in various OECD activities like hosting regional forums and attending workshops on issues including investment, taxation, financial education, private pensions, development and also has lent a supporting hand in the regionally focused activities in Asia carried out by the OECD. ${ }^{36}$ In a recent article of the Economic Times, it was published that the OECD chief Angel Gurria appreciated India's efforts to work with OECD and stated that the OECD members will be glad to welcome India into their group. ${ }^{37}$

\section{Application of OECD Principles in Indian Corporate Governance Regime}

Rights and Treatment of Shareholders: The corporate governance code of India has many major provisions which are in compliance with the OECD principles of corporate governance. Section 87 of the Companies $\mathrm{Act}^{38}$ provides for voting rights of shareholders in proportion to their shares in the paid up equity share capital of the company. The basic right of shareholders to secure the ownership rights by registration as mentioned in OECD principles is also provided in the Companies Act, 1956. The provision for transfer of shares is encapsulated in section 108 of the Companies Act and the provision of transmission of Shares is mentioned in section 109B.

Election and appointment of the board of directors by the shareholders is another OECD principle which is given in Chapter-III of the Companies Act 1956. Shareholders should have the opportunity to participate effectively and vote in general shareholder meetings and should be informed of the rules. The provision of annual general meeting is given in section 166 of the Companies Act. The provision of removal of directors which forms a part of the OECD principles is incorporated in section 284 and disqualification of directors in section 274. The procedure for giving notice is provided in sections 171,172 and 173 of the Companies Act. Voting through proxies, allowed with respect to certain conditions under section 179 of the Act. ${ }^{39}$

The corporate law in India also provides for certain provisions for the protection of minority shareholders as given in the OECD principles. Minority shareholders should be protected from abusive actions by controlling shareholders acting either directly or indirectly, and should have effective means of redress according to the OECD principles of

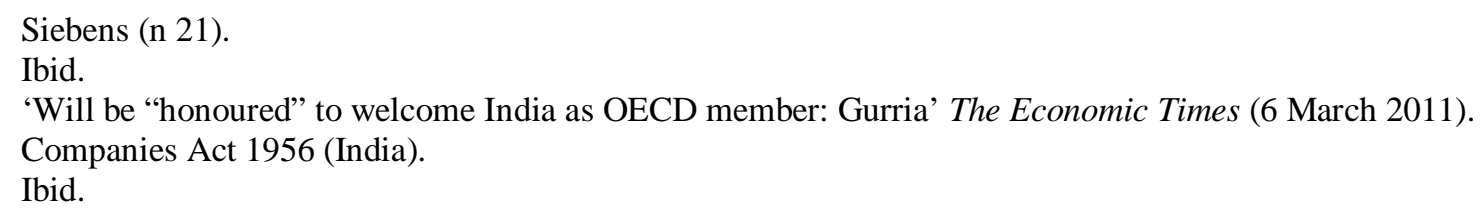


Corporate Governance. Section 399 of Companies Act provides for the protection of minority shareholders from oppression and discrimination by the majority shareholders in the company. Section 87 of the 1956 Act provides equitable voting rights to all shareholders who belong to the same class. Moreover, Section 91 of the Companies Act 1956 also calls for shares of same class to be made on a uniform basis. The major aim is to avoid differential treatment of shareholders who belong to the same class. Section 89 of the Companies Act provides for termination of disproportionately excessive voting rights and also incorporates the principle of equitable treatment to shareholders. The SEBI (Prohibition of Insider Trading) Regulations 1992 provides amended provisions for better disclosures on insider trading. This reflects the OECD principle which talks about prevention of insider trading for ensuring equitable treatment of shareholders.

\section{Role and Rights of Stakeholders}

The OECD principles of corporate governance requires the corporate governance framework to be complemented by an effective, efficient insolvency framework and state that there should be effective enforcement of creditors' rights. This is reflected in section 439 of the Companies Act ${ }^{40}$, which provides for the power to file a petition for winding up, subject to the reasons and restrictions mentioned in Section 433 of the Act by the creditors, contingent or prospective creditors and contributories. OECD principle states about the protection of the employees and also talks about providing them with retirement benefits so that their confidence in the company is restored. The provisions regarding employees' securities and provident funds are encapsulated in sections 417-419 of the Act. These provisions under the Companies Act guarantee the protection of the rights of the employees as the stakeholders of the company.

\section{Responsibility of the Board and Disclosure Requirements}

There are certain provisions in the Indian corporate governance code which are similar to the principle of board responsibility and the disclosure requirements as laid down under the OECD principles of corporate governance. Section 56 of the Act provides the matters that are to be stated in a prospectus. These disclosures would therefore ensure transparency in the functioning of the company. Section 13 of the Companies Act 1956 states that the inclusion of object clause in the Memorandum of Association of a Company is a necessary requirement. Disclosures in Articles of Association are also necessary requirements. These provisions reflect the OECD principle of maintenance of transparency by disclosures.

Statutory meetings and reports by the directors form a necessary requirement under disclosures according to section 165 of the Act. This helps in finding out whether the objectives mentioned in AoA and MoA are being fulfilled or not. This helps in ensuring transparency in the procedures of management. The financial status of the company can be verified through the annual accounts and the balance sheets. Section 210 of the

$40 \quad$ Lowenstein (n 16). 
CompanyAct states that the board of directors must lay before the company the balance sheet and a profit and loss account at every annual general meeting.

Clause 49 of Listing Agreement of SEBI states about the role of the Audit Committee in keeping a check on the company's financial reporting and reviewing the statement of funds. This reflects the OECD principle which lays down the provision that an annual audit should be conducted by an independent, competent and qualified auditor in order to provide an external and objective assurance to the board and shareholders. Appointment of auditors is dealt with in sec.224. Other disclosures with respect to related party transactions, accounting treatment, risk management procedures are also mentioned in clause 49 which are similar to the OECD principles of maintaining disclosures and transparency.

As regards the board's responsibility, section 291 states that the directors are expected to display utmost faith towards the company as they are appointed as the fiduciaries of the company. ${ }^{41}$ The directors are elected by the shareholders in the general meeting. According to section 255 of the Act, at least two-thirds of the board of directors should be rotational. This provision reflects the OECD principle of ensuring a formal and transparent board nomination and election process. A sufficient number of board members should not be employed by the company or closely related to the company or its management through significant economic, family or other ties under the OECD principles. The director shall not enter into any contract with the company for sale, purchase, etc. of goods without the consent of Board of Directors of the company according to section 297, Companies Act. There is another provision under which the members are required to disclose any material interests in transactions or matters affecting the corporation. The board has a responsibility to draft a fair report indicating its procedure of managing the company. This report consisting of all the related details about the company's affairs which shall be presented by the board in the annual general meeting according to section 217 of the Act.

The Board may consider establishing an audit committee according to OECD principles. A mandatory recommendation of SEBI states that a qualified and independent audit committee should be set up by the board of a company for the purpose for ensuring transparency and enhancing credibility. The Companies (Amendment) Act 1999 also contains detailed provisions in relation to audit committee, which reflect OECD principles.

\section{Critical Appraisal: Pros and Cons of OECD Principles}

The responsibilities of the board were articulated in detail in the principles, whereas proper focus was not given to areas of social interests such as employment relations. ${ }^{42}$ The OECD principles can be criticised on the basis of certain issues.

\footnotetext{
41 Companies Act 1956 (India) s 291; See also 'Corporate Governance in India: Current Status and Recommendations', <http://rbidocs.rbi.org.in/rdocs/PublicationReport/Pdfs/20024.pdf> 3April 2012. OECD (n 8).
} 
The principles represent convergence towards the anglo-American way of corporate governance which is culturally difficult to apply in countries which do not have the same legal tradition or economic situation. ${ }^{43} \mathrm{I} t$ is easy for the US and UK companies to adopt these principles but difficult for the Asian countries to adopt the anglo-American way of corporate governance due to the substantial social and cultural differences between developing Asian and Western economies. ${ }^{44}$ Most of the developing countries are now undergoing corporate governance reforms and adopting the anglo-American model of governance. ${ }^{45}$ The question which arises here is whether these countries are capable of implementing these principles effectively.

Certain changes will have to be brought to these economies. Family controlled and state controlled companies will have to be transformed into companies controlled by institutional shareholders and this necessary change in culture, which gives more powers to the shareholders, will increase the litigations and hence will adversely affect the interest of the citizens of these countries. ${ }^{46}$

Although the OECD principles of corporate governance includes the role and rights of stakeholders which is a unique feature, but from the analysis we can draw a conclusion that this part is not dealt with in detail. These principles represent the anglo-American way of corporate governance which is based on the share-holder's primacy form of governance. It is also important to notice that the role and rights of shareholders have been provided in extensive detail under the OECD principles of corporate Governance. The rise of shareholder primacy will adversely affect the interests of corporate of the stakeholders. ${ }^{47}$ In such form of corporate governance, the interests of shareholders are considered paramount by directors over and above those of other stakeholders, such as employees. Under this model of corporate governance, the stakeholders' interest will be unprotected and the whole purpose of a corporation of maximising long-term profit will be defeated.

But on the other hand, these principles alter the corporate governance systems of the countries to attract and suit foreign investors. ${ }^{48}$ If a country has a good corporate governance system, it will attract investors as they have confidence in the governance. Corporate governance ensures efficient and effective corporate management. The OECD principles

\footnotetext{
43 OECD (n 30).

44 Ibid.

45 Darryl Reed, 'Corporate Governance Reforms in Developing Countries' (2002) 37 Journal of Business Ethics, 223.

46 Siebens (n 11).

47 Malcolm Anderson et al, 'Evaluating The Shareholder Primacy Theory: Evidence From A Survey Of Australian <http://cclsr.law.unimelb.edu.au/files/Evaluating_the_shareholder_primacy_theory_evidence_from_a_ survey_of_Australian_directors_20_11_07_1.pdf> accessed 8 April 2012. Ibid.
} 
help to achieve this goal at a quicker pace than would be otherwise possible through new models of corporate governance by the respective countries. ${ }^{49}$

A number of Asian countries have adopted these standards of corporate governance principles for the purpose of improving the marketability of their capital markets after the Asian crisis. But only the adoption of the principles is not the solution, proper implementation is essential.

In India, the Harshad Mehta scam and the Satyam debacle are examples of failure of corporate governance principle of auditing process, misconduct of the directors and sheer mismanagement. This makes it very essential to have a proper corporate governance code and OECD principles of having an audit committee, principle of accountability and director's responsibility of acting with due diligence and proper care can be of substantial help.

The OECD principles can be resourceful in the management of corporation but some importance has to be given to the rights of the stakeholders by the corporate governance regimes of the countries following the OECD principles. This is to ensure the overall development of an economy which includes the welfare of all the stakeholders and their active participation in the activities of a corporation.

$* * * * * * * * * * * * * * * * * * *$

49 'Using the OECD Principles of Corporate Governance', <http://www.oecd.org/daf/ca/corporategovernanceprinciples/40823806.pdf> accessed 29 April 2013. 